5-1-2016

\title{
Early Growth and Development Impairments in Patients with Ganglioside GM3 Synthase Deficiency
}

H. Wang

Center for Special Needs Children

A. Wang

Center for Special Needs Children

Dan Wang

Center for Special Needs Children

A. Bright

Center for Special Needs Children

Folfoum thyis and additional works at: https://engagedscholarship.csuohio.edu/scichem_facpub

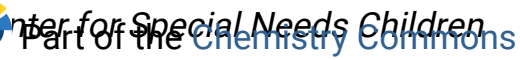

How does access to this work benefit you? Let us know!

Bedplis

This is the accepted version of the following article: Wang, H.; Wang, A.; Wang, D.; Bright, A.;

Sency, V.; Zhou, A.; Xin, B. Early growth and development impairments in patients with ganglioside GM3 synthase deficiency. Clin. Genet. 2016, 89, 625-629., which has been published in final form at http://onlinelibrary.wiley.com/doi/10.1111/cge.12703/abstract

\section{Recommended Citation}

Wang, H.; Wang, A.; Wang, Dan; Bright, A.; Sency, V.; Zhou, Aimin; and Xin, B., "Early Growth and Development Impairments in Patients with Ganglioside GM3 Synthase Deficiency" (2016). Chemistry Faculty Publications. 386.

https://engagedscholarship.csuohio.edu/scichem_facpub/386

This Article is brought to you for free and open access by the Chemistry Department at EngagedScholarship@CSU. It has been accepted for inclusion in Chemistry Faculty Publications by an authorized administrator of EngagedScholarship@CSU. For more information, please contact library.es@csuohio.edu. 


\section{Authors}

H. Wang, A. Wang, Dan Wang, A. Bright, V. Sency, Aimin Zhou, and B. Xin

This article is available at EngagedScholarship@CSU: https://engagedscholarship.csuohio.edu/scichem_facpub/386 


\title{
A rapid LC-MS/MS method for quantification of CSUOH0901, a novel antitumor agent, in rat
} plasma

\author{
Ramakrishna R. Voggu, Ravali Alagandula, Xiang Zhou, Bin Su, \\ Bo Zhong and Baochuan Guo
}

\section{Introduction}

CSUOH0901 \{benzo [1,3] dioxole-S-carboxylicacid [3-(2,5-dimethylbenzyloxy)-4-(methanesulfonylmethylamino)-phenyl] amide\} (NSC751382; Fig. 1C; Zhong et al., 2013) is a novel, secondgeneration anticancer agent derived from nimesulide, which can inhibit cyclooxygenase-2 (COX-2; Fig. 1A). In cancer therapy, nimesulide showed hepatotoxicity on long-term usage and required higher concentrations to inhibit COX-2 activity (Zhong et al., 2012). This led to the development of CSUOH0901, a nimesulide derivative, which exhibited very promising anticancer activities by interacting with tubulin and Hsp27 proteins, which are important to cancer cell proliferation. CSUOHO9O1 inhibited the proliferation of cancer cells of lung, breast, colon, CNS, ovary, renal and prostate cancer with an $\mathrm{IC}_{50}$ of 0.1-0.5 $\mu \mathrm{M}$ which is 10fold more active than JCC76 \{N-[3-(2,5-dimethylbenzyloxy)-4(methylmethylsulfonamido) phenyl] cyclohexanecaboxamide; (Fig. 1B; Suleyman et al., 2008) and 1000-fold more potent than nimesulide (Zhong et al., 2013).

Recent docking studies in SKBR-3 breast cancer cell lines (Suleyman et al., 2008; Yi et al., 2012) revealed that CSUOHO9O1 interacted with both a- and /J-tubulin in the colchicine pocket and disorganized microtubules. Additionally, interaction of heat shock protein 27 (Hsp27) (Sun and MacRae, 2005) with CSUOH0901 inhibited the phosphorylation of Hsp27, leading to cell apoptosis. Hsp27 is a stress protein that is expressed when cells are stimulated by heat (Kampinga et al., 1995; Stege et al., 1995a, 1995b), radiation (Rau et al., 1999), chemotherapeutic drugs (Ciocca et al., 1992) or other agents $\mathrm{Wu}$ and Welsh, 1996). A recent study showed that cancer cells with HSP27 overexpression were resistant to chemotherapeutic drugs (Huot et al., 1991; Fuqua et al., 1994; Hettinga et al., 1996; Richards et al., 1996). Antisense to inhibition of the HSP27 gene decreased cellular resistance to chemotherapy as well as to heat shock (Horman et al., 1999). Other studies have suggested that HSP27 prevents cancer cells from apoptosis and dramatically enhances their tumorigenicity (Garrido et al., 1998, 1999; Guenal et al., 1997; Samali and Cotter, 1996). Mass spectrometric studies revealed that tubulin and Hsp27 proteins are the most prevalent targets of CSUOH0901. Recent in vivo studies demonstrated that CSUOH0901 significantly decreased the size of HT29 tumors in a xenograft model compared with the control group, suggesting the low toxicity and high potency in vivo (Zhong et al., 2012).

Clearly, CSUOH0901 is a very promising anticancer drug candidate and will be further studied. However, to date, no LCMS/MS method has been developed for the quantification of CSUOH0901. Therefore, a simple and accurate method to quantify $\mathrm{CSUOHO901}$ is needed that will be essential to the future pharmacological and toxicological studies of CSUOH0901. In this work, a rapid and sensitive LC-MS/MS method was developed and validated for quantitative determination of CSUOHO9O1 in rat plasma. We demonstrated that the method developed was 
(A)<smiles>CS(=O)(=O)Nc1ccc([N+](=O)[O-])cc1Oc1ccccc1</smiles>

Nimesulide

(C)<smiles>Cc1ccc(C)c(COc2cc(NC(=O)c3ccc4c(c3)OCO4)ccc2N(C)S(C)(=O)=O)c1</smiles>

\section{CSUOH0901}

Figure 1 The chemical structures of nimesulide (A), internal standard JCC76 (B) and CSUOH0901 (Q.

fast, sensitive and specific for quantifying CSUOHO9O1 in plasma, and can be used in pharmacological studies.

\section{Experimental}

\section{Chemical and reagents}

CSUOH0901 and JCC76 (internal standard, 15) were synthesized and pu rified according to the previously published procedures (Zhong et al,, 2013; Suleyman et al., 2008). HPLC grade methanol and acetonitrile were purchased from Pharmco Apper (Philadelphia, PA USA). Formic acid, ammonium formate and ammonium acetate were purchased from Sigma Aldrich Chemical Company (Allentown, PA, USA). Dimethyl sulfox ide was obtained from Fisher Scientific (Pittsburgh, PA USA). Deionized water was generated from a Barnstead Nano Pure Water Purification Sys tern from Thermo Scientific (Waltham, MA, USA). Sprague Dawley rat plasma $K 2$ with specific lot numbers (10577 or 06) was purchased from Innovative research (Novi, Ml, USA).

\section{Calibration standard and quality control samples}

Preparation of stock and working solutions. The stock solutions of CSUOH0901 and JCC76 (IS) were prepared in dimethyl sulfoxide (DMSO) at $1 \mathrm{mg} / \mathrm{ml}$ and stored at $20^{\circ} \mathrm{C}$. A set of $\mathrm{CSOHO901}$ working solutions of $10,20,50,150,400,1000$ and $2000 \mathrm{ng} / \mathrm{ml}$ were prepared by serial dilu tion from the stock solution with DMSO. The working solution of JCC76 (IS) was obtained by diluting the stock solution with DMSO to give a con centration of $150 \mathrm{ng} / \mathrm{ml}$.

Preparation of calibration and quality control plasma sam pies. The calibration plasma solutions were prepared by spiking $10 \mu \mathrm{L}$ of CSUOHO9O1 working solutions in $200 \mu \mathrm{L}$ of blank plasma (mixture of 6 lots) to give drug concentrations of $0.5,1.0,2.5,7.5,20,50$ and 100 $\mathrm{ng} / \mathrm{mL}$ The lower limit of quantification (LOQ) and quality control (QC) standards were prepared in a similar way at $0.5,1.25,10,80 \mathrm{ng} / \mathrm{ml}$, representing $\amalg O Q$, low $Q C(L Q C)$, middle $Q C$ (MQC) and high $Q C(H Q()$ respectively. The $\propto$ and calibration samples were frozen at $20^{\circ} \mathrm{C}$ over night. and then treated by the following sample preparation procedure and subjected to $L$ MS/MS analysis.

\section{Sample extraction}

Plasma samples were removed from the $20^{\circ} \mathrm{C}$ freezer and thawed to room temperature. Single and double blanks were prepared by spiking $10 \mu \mathrm{L}$ of acetonitrile in $200 \mu \mathrm{L}$ of rat plasma. Then $10 \mu \mathrm{L}$ of $\mathrm{S}$ working solution was spiked in all calibration, $Q$ colutions and single blank. ex cept in double blank and vortexed immediately for $30 \mathrm{~s}$ The samples were deproteinized by adding $800 \mu \mathrm{L}$ of acetonitrile and sonicated for $15 \mathrm{~min}$ followed by centrifugation at $13,000 \mathrm{~g}$ for $15 \mathrm{~min}$. The superna tants were transferred into autosampler vials for $L \mathrm{C}$ MS/MS analysis.

\section{LC-MS/MS analysis}

LC MS/MS analysis was conducted using 5500 QTRAP triple quadrupole, tandem mass spectrometer (AB Sciex, Toronto, Canada) with an electrospray ionization ESO source (Framingham, MA, USA) interfaced with high performance liquid chromatography (HPLC, Shimadzu, Columbia, MD, USA) with two LC 30 AD pumps, DUG 20A3R inline degasser, a SL 30 AC autosampler, a CBM 20A controller and a CTO 10AVP column oven (Shimdazu, Tokyo, Japan). Analyst software, version 1.52 (AB Sdex) was used to control all the parameters of tandem mass spectrometer and HPLC.

A Luna $C_{18}$ (2) HPLC column $(50 \times 2.0 \mathrm{~mm} 5 \mu \mathrm{m})$ with a $C_{18}$ security guard cartridge from Phenomenex (Torrance, CA, USA) was used for the chromatographic separation of the supernatants from the deproteinized samples. An optimized gradient flow of mobile phase A, $5 \mathrm{mM}$ ammonium formate in $2 \%$ methanol, and mobile phase B, $5 \mathrm{mM}$ ammonium formate in $90 \%$ methanol at a flow rate of $02 \mathrm{mUmin}$, was developed. The column was equilibrated with the mobile phase for 10 min and the run time was $8 \mathrm{~min}$ for each run with $10 \mu \mathrm{L}$ injection vol ume. The positive ES mode was selected and the MRM (multiple reac tion monitoring) function was used for quantification, with the transitions set at $m / z 483.2-+404.3, \mathrm{rn} / \mathrm{z} 4832-+119.0$ for CSUOH0901 and $m / 2445.3-+3663$ for JCC76 (IS) (Fig. 2). The dwell time for each MRM transition was set at $120 \mathrm{~ms}$. Source dependent parameters were optimized by flow infusion analysis: nebulization gas (30), heating gas (30), curtain gas (40), ion spray voltage $(5000 \mathrm{eV}$ ) and temperature $\left(450^{\circ} \mathrm{C}\right)$. Compound dependent parameters were manually optimized as following: declustering potential, 180; entrance potential, 1Q collision energy, 20; and cell exit potential, 12

\section{Analytical method validation}

A full method validation was performed using rat plasma according to the currently accepted FDA bioanalytical method guidelines (US Food and Drug Administration, 2001) and also other references (Liu et al. 2013; Ito et all, 2013). The entire method was validated for precision, ac curacy, linearity, selectivity, extraction recovery, $\llcorner O Q$, matrix effect and stability studies.

Calibration curve, linearity and sensitivity. Seven CSUOHO901 plasma calibrators at the concentrations of $0.5,1.0,2.5,7.5,20,50$ and $100 \mathrm{ng} / \mathrm{ml}$, double blank and single blank (only JCC76 internal standard) were selected to establish a calibration curve. The weighed linear reg res sion, $1 / x$, as weighing factor was used to calculate the slope and correla tion coefficient of the calibration curve. The LLOQ was defined as the concentration with precision (coefficient of variation, CV) $<20 \%$.

Accuracy and precision. Intra and inter assay precision and accuracy studies were performed using three $\propto$ C standards, $L Q C, M Q C$ and $H Q C$, at $1.25,10$ and $80 \mathrm{ng} / \mathrm{ml}$ with five replicates $(n=5)$. Intra and inter assay precisions were determined as $\mathrm{CV}$, and accuracies were cakulated by comparing experimentally determined concentrations with the spiked values. Therefore, accuracy $(\%)=[($ experimental concentration spiked concentration)/ spiked concentration) $\times 100$.

Recovery and matrix effect. The absolute extraction recovery was determined by comparing the peak areas of CSUOH0901 in $Q$ C samples at $1.25,10$ and $80 \mathrm{ng} / \mathrm{ml}$ (CSUOH0901 added prior to deproteinization) with those of postextraction samples (CSUOH0901 added after 
(A)

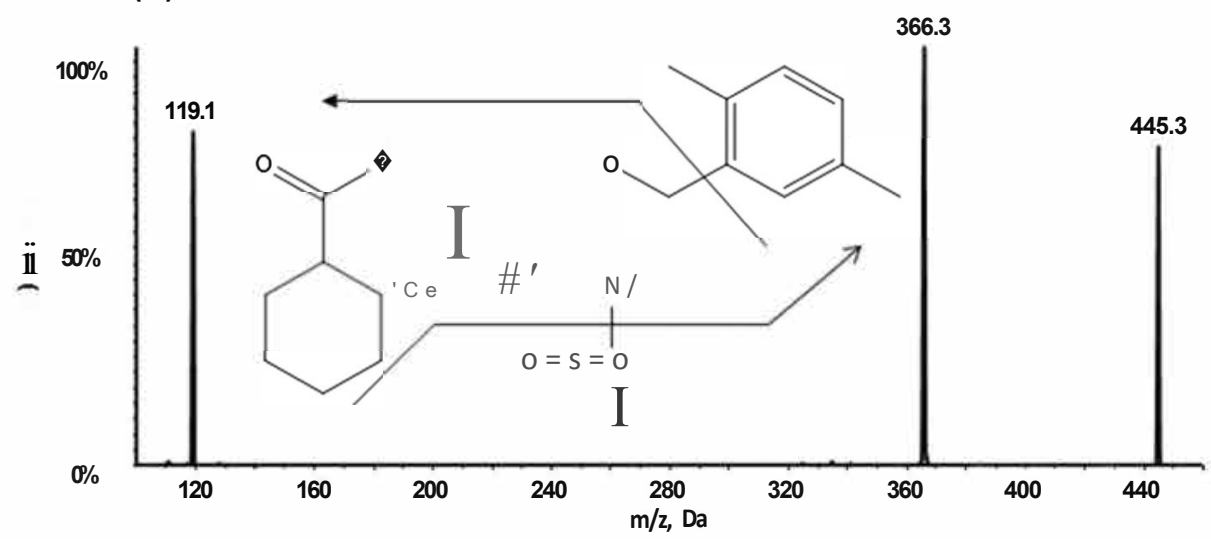

(B)

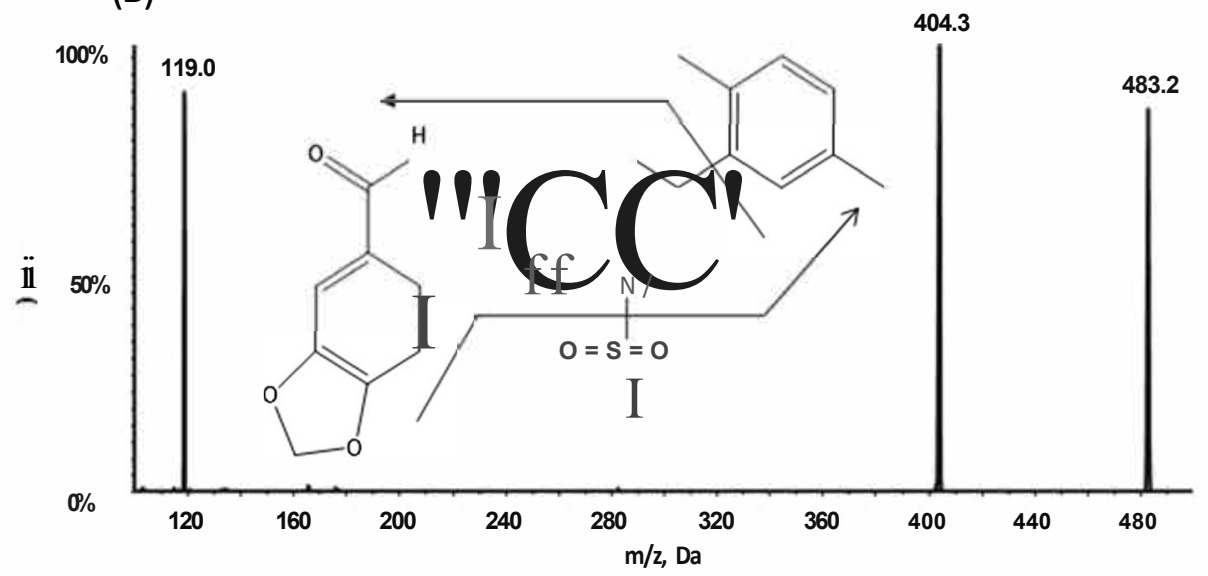

Figure 2. Precursor/product ion spectra and proposed fragmentation pathways for internal standard JCC76 (A) and analyte CSUOH0901 (B).

deproteinization) of corresponding concentrations. The relative recovery was determined by comparing peak area ratio of CSUOHO9O1 and S (JCC76) spiked in plasma before extraction with that in postextraction spiked samples.

The absolute matrix effect was calculated by comparing the peak areas of postextraction blank plasma samples spiked with CSUOHO9O1 $(1.25,10$ and $80 \mathrm{ng} / \mathrm{ml})$ with those of corresponding standard solutions at equivalent concentrations. The relative matrix effect was calculated by comparing the peak area ratio of CSUOH0901 and S (JCC76) spiked in the blank plasma postextraction solution with that in standard solution.

\section{Stability studies}

Effect of freeze thaw on CSUOH0901 in plasma. Two QC samples of 1.25 and $80 \mathrm{ng} / \mathrm{ml}$ concentrations were selected to verify their stabil ity. The stability test for CSUOHO9O1 in plasma was studied after three freeze thaw cycles over a 3 day period.

Short- and long-term stability studies of analyte in plasma. The stability studies of CSUOH0901 in rat plasma were performed using two QC standards $(1.25$ and $80 \mathrm{ng} / \mathrm{ml})$, which were kept under different storage conditions: $10 \mathrm{~h}$ at room temperature and 6 months at $20^{\circ} \mathrm{C}$, before and after sample extraction.

Stability of analyte in stock solutions. The stability studies of stock solutions and working solutions of CSUOHO9O1 and internal standard (JCC76) were also evaluated. The stock solutions of analyte were stored at $20^{\circ} \mathrm{C}$ for 7 months. Two QC standards of concentrations 1.25 and $80 \mathrm{ng} / \mathrm{ml}$ were prepared from both the stored and fresh stock solutions and the experimentally determined concentrations of CSUOHO9O1 were compared ( $n=3$ for each sample).

\section{Results and discussion}

\section{Optimization of mass spectrometric conditions for MRM quantitation}

Positive ionization mode was selected to detect and optimize the MS parameters for the detection of both CSUOH0901 and JCC76 (internal standard). It was found that the standard CSUOHOOO1 and JCC76 solutions prepared in methanol-water (9:1, v/v) yielded higher intensity when compared with the solutions prepared in acetonitrile-water $(9: 1, v / v)$. Fragmentation led to the formation of daughter ions in the product ion scan mode (Fig. 2). Based on the fragmentation study, the MRM transitions of $\mathrm{m} / \mathrm{z}$ $483.2 \rightarrow 404.3$ for CSUOH0901 and $445.3 \rightarrow 366.3$ for JCC76 were selected for quantification, as these product ions yielded strong signals. The highest MS signal was obtained by fine-tuning collision energy, spray voltage and ion source temperature.

\section{Optimization of HPLC conditions}

To overcome the irreproducibility and matrix effect problems associated with the isocratic flow, a gradient flow of mobile phase A, SmM ammonium formate in $2 \%$ methanol, and mobile phase B, $5 \mathrm{mM}$ ammonium formate in $90 \%$ methanol with $0.2 \mathrm{ml} / \mathrm{min}$ flow rate, was employed. This gradient flow improved the sensitivity and signal-to-noise ratio with a total run time of $18 \mathrm{~min}$. High concentration of methanol was used to elute CSUOHO9O1 from ( 18 column, owing to its low solubility in water with 
(A)
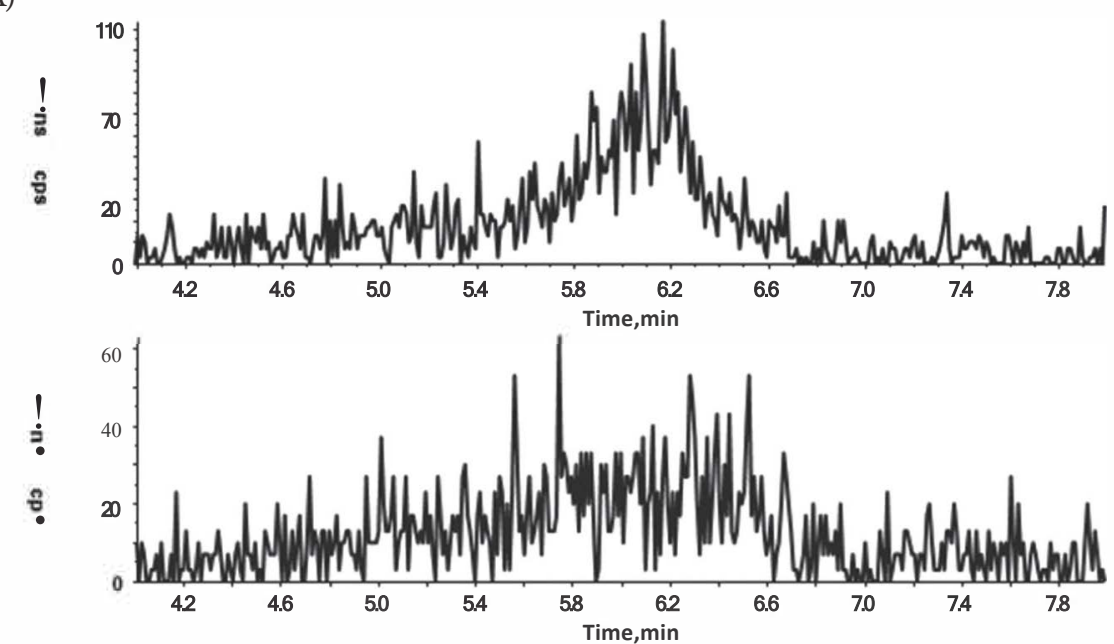

(B)
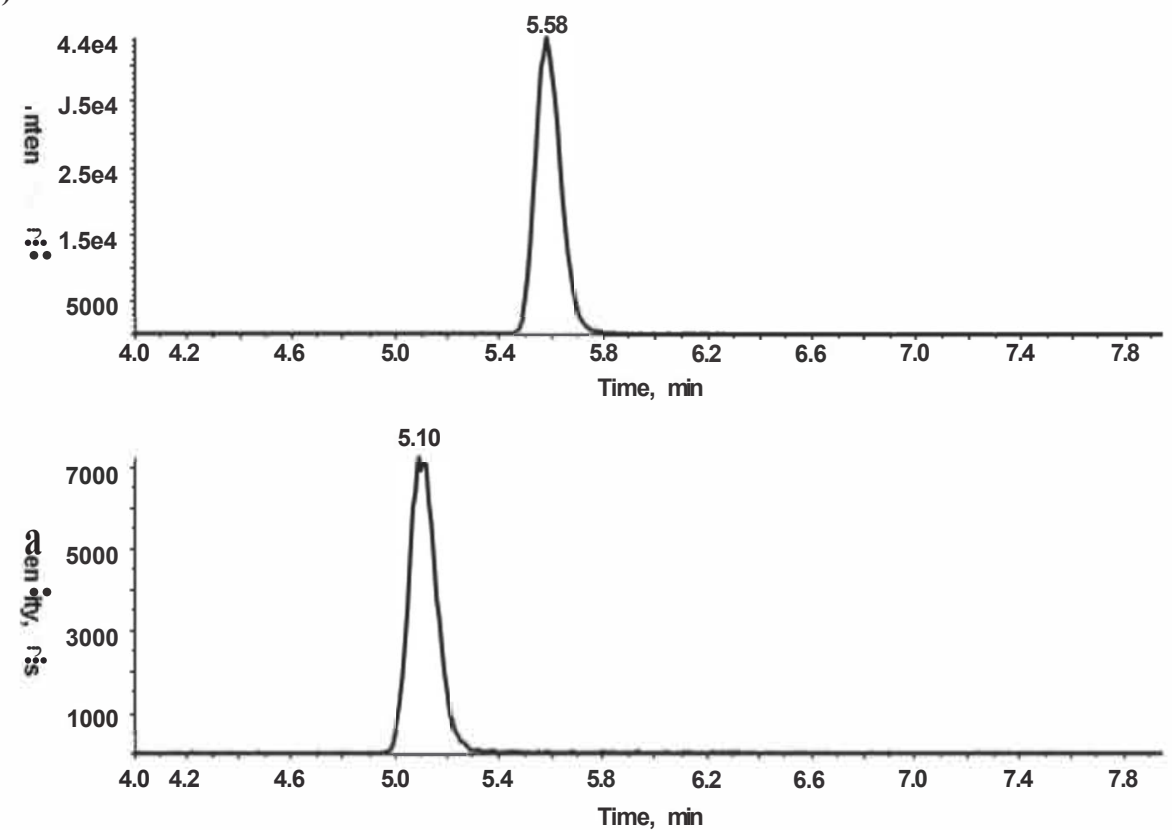

Figure 3 (A) Multiple reaction monitoring chromatograms of blank rat plasma in both $\mathrm{S}$ and analyte windows. (B) $\mathrm{S} J C C 76$ (10 $\mathrm{ng} / \mathrm{ml}, \mathrm{S} .58 \mathrm{~min})$ and CSUOH0901 at LLOQ level $(0.5 \mathrm{ng} / \mathrm{ml}, 5.10 \mathrm{~min})$.

predicted logo value of 4.86. The intensity of CSUOH0901 was increased 2-fold when $5 \mathrm{mM}$ ammonium formate buffer was used in the mobile phases and the retention times were around $5.09 \mathrm{~min}$ for CSUOH0901 and $5.58 \mathrm{~min}$ for JCC76 (IS) (Fig. 38).

\section{Linearity, sensitivity, selectivity and LLOQ}

the Calibration curve for CSUOH0901 in plasma was linear in the range of $0.5-100 \mathrm{ng} / \mathrm{ml}$. Linearity results showed the quadratic fit for CSUOH0901 with a seven-point calibration curve of concentrations $0.5,1.0,2.5,7.5,20,50$ and $100 \mathrm{ng} / \mathrm{ml}$ including double-blank and single-blank (only JCC76 internal standard) plasma samples. An excellent linearity was obtained with the correlation coefficient of 0.9996 and the linear regression equation was $y=0.073 \mathrm{x} \quad 0.0085$. This method exhibited high selectivity with no interfering peak in six different blank plasma samples from different sources. The LLOQ was found to be 0.5 $\mathrm{ng} / \mathrm{ml}$, where the signal intensity was 20-fold higher than the blank signal (Fig. 3). The lowest concentration in a calibration curve (LLOQ) was quantified with the accuracy and precision within 15\% (Table 1)

Table 1 Accuracy and precision of CSUOH0901 calibration standards $(n=5$ ) over $0.5-100 \mathrm{ng} / \mathrm{ml}$

\begin{tabular}{lcrr}
$\begin{array}{l}\text { Nominal } \\
\text { concentration }\end{array}$ & $\begin{array}{c}\text { Determined } \\
\text { concentration }\end{array}$ & Accuracy & Precision \\
\hline (ng/ml) & $(\mathrm{ng} / \mathrm{ml})$ & (RE) & (CV) \\
\hline 0.5 & $0.49 \pm 0.01$ & $2.0 \%$ & $4.5 \%$ \\
1 & $0.90 \pm 0.09$ & $10.0 \%$ & $6.0 \%$ \\
25 & $2.58 \pm 0.08$ & $3.2 \%$ & $6.7 \%$ \\
7.5 & $7.23 \pm 0.27$ & $3.6 \%$ & $11.0 \%$ \\
20 & $20.42 \pm 0.42$ & $2.1 \%$ & $1.7 \%$ \\
50 & $49.14 \pm 0.86$ & $1.7 \%$ & $1.6 \%$ \\
100 & $97.30 \pm 2.70$ & $2.7 \%$ & $2.2 \%$
\end{tabular}


Table 2. Inter- and intra-assay accuracy and precision of CSUOHO9O1 in rat plasma

\begin{tabular}{|c|c|c|c|c|c|c|c|c|}
\hline \multicolumn{5}{|c|}{ Intra- assay } & \multicolumn{4}{|c|}{ Inter- assay } \\
\hline $\begin{array}{l}\text { Spiked } \\
\text { (ng/ml) }\end{array}$ & $\begin{array}{l}\text { Determined } \\
(\mathrm{ng} / \mathrm{ml})\end{array}$ & $\begin{array}{c}\text { Accuracy } \\
\text { (\%RE) }\end{array}$ & SD & $\begin{array}{l}\text { Precision } \\
\text { (CV) }\end{array}$ & $\begin{array}{l}\text { Determined } \\
(\mathrm{ng} / \mathrm{ml})\end{array}$ & $\begin{array}{l}\text { Accuracy } \\
\text { (RE) }\end{array}$ & SD & $\begin{array}{c}\text { Precision } \\
\text { (CV) }\end{array}$ \\
\hline 1.25 & 1.39 & $11.2 \%$ & 0.04 & $2.9 \%$ & 1.39 & $11.2 \%$ & 0.07 & $5.0 \%$ \\
\hline 10 & 10.26 & $2.6 \%$ & 0.18 & $1.8 \%$ & 10.35 & $3.5 \%$ & 0.46 & $4.5 \%$ \\
\hline 80 & 78.52 & $1.9 \%$ & 1.44 & $1.8 \%$ & 79.58 & $0.5 \%$ & 4.36 & $5.5 \%$ \\
\hline
\end{tabular}

\section{Accuracy and precision}

Intra- and inter -assay accuracies of the validated method ranged from 1.9 to $11.2 \%$ and from 0.5 to $11.2 \%$, respectively. The intraand inter-assay precision values ranged from 1.8 to $2.9 \%$ and from 4.5 to $5.5 \%$, respectively. The inter- and intra-assay accuracy and precision of the QC samples are depicted in Table 2.

\section{Extraction recovery and matrix effect}

The absolute recoveries of the extraction method were 104.0, 105.0 and $104.0 \%$ for the QC standards at $1.25,10$, and 80 $\mathrm{ng} / \mathrm{ml}$, and the relative recoveries of the extracted method were 99.9, 96.1 and $97.7 \%$ for the QC standards at 1.25, 10, and 80 $\mathrm{ng} / \mathrm{ml}$, respectively, as indicated in Table 3. Absolute matrix effects for each of three plasma samples at 1.25, 10, and 80 $\mathrm{ng} / \mathrm{ml}$ were $5.5,81$ and $9.9 \%$, and relative matrix effects were 2.6, 5.1 and $12.4 \%$ indicating the minimal matrix effect. Hence, the protein precipitation technique for sample preparation was found to be effective, as it not only extracted the analyte and internal standard well but also removed impurities causing interferences from the sample matrix.

Performing MRM confirmed the absence of significant matrix effect by comparing the peak areas ratio of CSUOH0901 MRM transitions $\left(\mathrm{MRM}_{1}, \mathrm{~m} / \mathrm{z} 483.2 \rightarrow 404.3\right.$; and $\mathrm{MRM}_{2}, \mathrm{~m} / \mathrm{z} 483.2$ $\rightarrow 119.0)$ for the spiked rat plasma samples with the average peak area ratio for seven calibrators:

$\mathrm{MRM}$ ratio $=$ peak area $\mathrm{MRM}_{1} /$ peak area $\mathrm{MRM}_{2}$

The average MRM ratio of the seven calibrators was $15 \pm 1.9$ $( \pm S D)$. This confirmed the absence of matrix effect in the plasma samples and that they are in the acceptable range.

\section{Stability}

CSUOH0901 was stable for at least $8 \mathrm{~h}$ at room temperature (bench top) and for $10 \mathrm{~h}$ when postextracted at room temperature and the results were summarized in Table 4. The recovery of

Table 3. Absolute and relative matrix effect and recovery of CSUOH0901 in rat plasma

\begin{tabular}{|c|c|c|c|c|}
\hline \multirow{2}{*}{$\begin{array}{l}\text { Concentration } \\
\text { of } \mathrm{QC} \text { samples } \\
(\mathrm{ng} / \mathrm{ml})\end{array}$} & \multicolumn{2}{|c|}{ Matrix effect } & \multicolumn{2}{|c|}{ Recovery } \\
\hline & Absolute & Relative & Absolute & Relative \\
\hline 1.25 & $5.5 \%$ & $2.6 \%$ & $104.0 \%$ & $99.9 \%$ \\
\hline 10 & $8.1 \%$ & $5.1 \%$ & $105.0 \%$ & $96.1 \%$ \\
\hline 80 & $9.9 \%$ & $12.4 \%$ & $104.0 \%$ & $97.7 \%$ \\
\hline
\end{tabular}

\begin{tabular}{|lrc|}
\hline Table 4. Stabilities of CSUOHO901 & under various conditions \\
Stability & $\begin{array}{c}\text { Concentration } \\
(\mathrm{ng} / \mathrm{ml})\end{array}$ & $\begin{array}{c}\text { Recovery } \\
(\%)\end{array}$ \\
\hline Bench-top (8 h) & 1.25 & $112.0 \%$ \\
At room temperature & 80.00 & $99.1 \%$ \\
Freeze-thaw (three cycles) & 1.25 & $112.0 \%$ \\
& 80.00 & $104.5 \%$ \\
Post-extraction (10 h) at room & 1.25 & $106.4 \%$ \\
temperature & 80.00 & $97.8 \%$ \\
\hline
\end{tabular}

Table 5. Stabilities of CSUOH0901 and JCC76 Stock solutions after storage at $20^{\circ}$ ( for 6 months

Type of solutions Concentration Recovery (\%)

$\begin{array}{lcr}\text { CSUOH0901 stock solution } & 1 \mathrm{mg} / \mathrm{ml} & 111.8 \% \\ \text { JCC76 stock solution } & 1 \mathrm{mg} / \mathrm{ml} & 106.0 \% \\ \text { CSUOH0901 working solution } & 25 \mathrm{ng} / \mathrm{ml} & 99.6 \% \\ & 1600 \mathrm{ng} / \mathrm{ml} & 105.0 \% \\ \text { JCC76 working solution } & 150 \mathrm{ng} / \mathrm{ml} & 124.6 \%\end{array}$

CSUOH0901 was $112.0 \%$ at LQC and $104.5 \%$ at HQC levels after three freeze-thaw cycles. Stability studies of stock solutions and working solutions of CSUOH0901 and internal standard (JCC76) were performed by storing them at $20^{\circ}$ ( for at least 6 months. The analyte and the internal standard were found to be stable in stock solutions and the results are summarized in Table 5.

\section{Conclusion}

In conclusion, a highly sensitive LC-MS/MS method for the quantitation of CSUOH0901 in rat plasma was developed and validated for the first time. The method developed has a short run time of 18 min employing a simple one-step sample preparation. The accuracy and precision were $<10 \%$ and the LLOQ was as low as $0.5 \mathrm{ng} / \mathrm{ml}$. The results from the validation studies illustrated that this method can be used to determine the pharmacological and toxicological profiles of $\mathrm{CSUOHO9O1} \mathrm{in} \mathrm{rats.}$

\section{Acknowledgments}

We thank Cleveland State University for providing the financial support of this research. We also acknowledge The National Science Foundation Major Research Instrumentation Grant (CHE0923398), which supported the use of the AB Sciex QTrap 5500 mass spectrometer instrument in the current project. 


\section{References}

Ciocca DR, Fuqua SA, Lock Lim S, Toft DO, Welch WJ and McGuire WL. Re sponse of human breast cancer cells to heat shock and chemothera peutic drugs. Cancer Research 1992; 52: 36483654.

Fuqua SA, Oesterreich S, Hilsenbeck SG, Von Hoff DD, Eckardt J and Os borne CK. Heat shock proteins and drug resistance. Breast Cancer Re search and Treatment 1994; 32: 6771.

Garrido C, Fromentin A, Bonnette B, Favre N, Moutet M, Arrigo AP, Mehlen $P$ and Salary E Heat shock protein 27 enhances the tumori genicity of immunogenic rat colon carcinoma cell clones. Cancer Research 1998; 58: 54955499.

Garrido C, Bruey JM, Fromentin A, Hammann A, Arrigo AP and Salary E HSP27 inhibits cytochrome c dependent activation of procaspase 9. Federation of American Societies for Experimental Biology 1999; 13: 20612070.

Guenal I, Sidoti FC, Gaumer Sand Mignotte B. Bel 2 and Hsp27 act at dif ferent levels to suppress programmed cell death. Oncogene 1997; 15: 347360 .

Hettinga JV, Lemstra W, Meijer C, Los G, de Vries EG, Konings AW and Kampinga $\mathrm{HH}$. Heat shock protein expression in cisplatin sensitive and resistant human tumor cells. International Journal of Cancer 1996; 67: 800807.

Horman S, Fokan D, Mosselmans R, Mairesse N and Galand P. Anti sense inhibition of small heat shock protein (HSP27) expression in MCF 7 mammary carcinoma cells induces their spontaneous acquisition of a secretory phenotype. International Journal of Cancer 1999; 82:574 582 .

Huot J, Roy G, Lambert H, Chretien P and Landry J. Increased survival af ter treatments with anticancer agents of Chinese hamster cells ex pressing the human Mr 27,000 heat shock protein. Cancer Research 1991; 51: 52455252.

Ito $\mathrm{H}$, Yamaguchi $\mathrm{H}$, Fujikawa A, Shiida N, Tanaka N, Ogura J, Kobayashi M, Yamada T, Mano N and Iseki K, Quantification of intact carboplatin in human plasma ultrafitrates using hydrophilic interaction liquid chromatography tandem mass spectrometry and its application to a pharmacokinetic study. Journal of Chromatography B: Analyti cal Technologies in the Biomedical and Life Sciences 2013; 917 918: 1823.

Kampinga $\mathrm{HH}$, Brunsting JF, Stege GJ, Burgman PW and Konings AW. Thermal protein denaturation and protein aggregation in cells made thermotolerant by various chemicals: role of heat shock proteins. Experimental Cell Research 1995; 219: 536546.

Liu Y, Ma B, Zhang Q Ying H, L J, Xu Q, Wu D and Wang Y. Development and validation of a sensitive liquid chromatography/tandem mass spectrometry method for the determination of raddeanin $A$ in rat plasma and its application to a pharmacokinetic study. Journal of Chromatography B Analytical Technologies in the Biomedical and Life Sciences 2013; 912: 1623.

Rau B, Gaestel M, Wust P, Stahl J, Mansmann U, Schlag PM and Benndorf $\mathrm{R}$ Preoperative treatment of rectal cancer with radiation, chemother apy and hyperthermia: analysis of treatment efficacy and heat shock response. Journal of Radiation Research 1999; 151: 479488.

Richards EH, Hickey E, Weber Land Master JR. Effect of overexpression of the small heat shock protein HSP27 on the heat and drug sensitivities of human testis tumor cells. Cancer Research 1996; 56: 24462451.

Samali A and Cotter TG. Heat shock proteins increase resistance to apoptosis. Experimental Cell Research 1996; 223: 163170.

Stege GJ, Brunsting JF, Kampinga HH and Konings AW. Thermotolerance and nuclear protein aggregation: protection against initial damage or better recovery? Journal of Cellular Physiology 1995a; 164: 579586.

Stege GJ, Kampinga $\mathrm{HH}$ and Konings AW. Heat induced intranuclear pro tein aggregation and thermal radiosensitization. International Journal of Radiation Biology 1995b; 67: 203209.

Suleyman H, Cadirci E, Albayrak A and Halici Z Nimesulide is a selective COX 2 inhibitory, atypical non steroidal anti inflammatory drug. Cur rent Medicinal Chemistry 2008; 15: 278283.

Sun $Y$ and MacRae TH. The small heat shock proteins and their role in hu man disease. Federation of European Biochemical Societies 2005; 272: 26132627.

US Food and Drug Administration. Bioanalytical Method Guidelines for In dustry. US Department of Health and Human Services, Food and Drug Administration, 2001. Available from: www.fda.gov/downloads/ Drugs/Guidances/ucm070107.pdf

Wu W and Welsh MJ. Expression of the $25 \mathrm{kDa}$ heat shock protein (HSP27) correlates with resistance to the toxicity of cadmium chloride, mercuric chloride, cis platinum(II) diammine dichloride, or sodium ar senite in mouse embryonic stem cells transfected with sense or anti sense HSP27 CDNA. Toxicology and Applied Pharmacology 1996; 141: 330339.

Yi X, Zhong B, Smith KM, Geldenhuys WJ, Feng Y, Pink J], Dowlati A, Xu Y, Zhou $A$ and Su B. Identification of a class of novel tubulin inhibitors. Journal of Medicinal Chemistry 2012; 55: 34253435.

Zhong B, Cai X, Chennamaneni S, Yi X, Liu L, Zhong B, Cai $X$, Chennamaneni S, Yi X, Liu L, Pink JJ, Dowlati A, Xu Y, Zhou A and Su B From COX 2 inhibitor nimesulide to potent anti cancer agent: synthesis, in vitro, in vivo and pharmacokinetic evaluation. European Journal of Medicinal Chemistry 2012; 47: 432444.

Zhong B, Chennamaneni S, Lama R, Yi X, Geldenhuys WJ, Pink JJ, Dowlati A, Xu Y, Zhou A and Su B. Synthesis and anticancer mechanism inves tigation of dual Hsp27 and tubulin inhibitors. Journal of Medicinal Chemistry 2013; 56: 53065320. 